\title{
ESTONIAN NATURALISTS' SOCIETY
}

Associated with

the Estonian Academy of Sciences

23.01.1998

Founded in 1853

Membership: 693 active members, 15 honorary members, 631 trustees

Divisions: 22

Location: Struve 2, 51003 Tartu, ESTONIA

Address: PO 43, 50001 Tartu, ESTONIA, elus@elus.ee

www.elus.ee

President: Oive Tinn, phone: +372 734 1935, +372 53331556

Academic Secretary: Ivar Ojaste, phone: +372 7341935

Estonian Naturalists' Society has 22 divisions. Divisions which perform as scientific sections are as follows: the section of amateur meteorologists, of anthropology, of botany, of entomology, of forestry, of geology, and of theoretical biology; the Commission of Lakes, the Estonian Malacological Society, the Estonian Mycological Society, the Estonian Teriological Society and the Jakob von Uexküll Centre. Commissions with special tasks focus on the history of natural sciences, the library, natural history education, observation station networks, the terminology of ecology and plant names, and botanical rarities. In addition, the Society comprises councils of ecology, of honorary members and the round table of nature conservation.

In 2016 ten General Assemblies with scientific presentations were held:

January 28 - Mare Ainsaar: "When do humans go extinct?";

March 1 - seminar "Baer's Day” in honour of embryologist Karl Ernst von Baer, with talks given by Erki Tammiksaar: "Autobiography of K. E. von Baer in Estonian" and by Martin Kärner: "Sea urchin as a model in developmental biology during Baer's time and today"; 
April 28 - Peep Männil: "The Golden jackal - how alien species develop into native species";

September 29 - Peeter Somelar: "How did Hannibal cross the Alps with war elephants?";

October 27 - Merle Muru: "Human settlement in Tallinn during the New Stone Age";

November 24 - Mait Metspalu: "Archeogenetics and human evolution";

December 16 - Tõnu Viik: "Water outside of the Earth".

The 39th Naturalists' Day was held in in Olustvere, Viljandi County, on July $2-3$. Field trips and workshops were organized to study local vascular plants, lichens, stem decay fungi and dragonflies. Five scientific talks were presented, most of which were focused on the biological diversity and geology of Viljandi County. An excursion was organized in the neighbourhood.

The activities of the divisions of the ENS during 2016 were the following:

The Section of Geology - the XII Geology Autumn School on the main subject "Sea" was organized at Roosta, Lääne County, on 14-16 October. 18 scientific talks were presented and an excursion to study the coastal structures of the early stages of the Baltic Sea was organized. The papers were published in the collection Schola Geologica XII (135 pp.)

The Section of Theoretical Biology - The XliI Spring School "Life's hidden patterns" was organized at Ruusa, Põlva County, on 20-22 May. 15 scientific talks were given. The papers were published in the collection Schola Biotheoretica XLII “Life's hidden patterns" (172 pp.).

The Section of Botany - May 28-29 - the annual gathering of 'friends of mosses', attended by 25 participants and visiting the Mustoja Nature Reserve, Kuresoo and Lüübnitsa at Setomaa. 76 moss species were registered. in the course of a field trip. The new issue of the internet journal Friend of mosses, 19 was compiled.

The observers' network of the Section of Amateur Meteorologists continued their work. The weather observation station at Jõgeva received data from 43 amateur stations. 18 stations of all amateur observation stations meas- 
ured precipitation in the warmer half of the year only; the others also made snow observations during winter time. The weather data (minimum and maximum air temperature, amount of precipitation, snow thickness and extent of snow canopy in the area, atmospheric phenomena) were documented, compared and processed provisionally. Based on the collected data, crucial agro-meteorological indicators were determined, and were subsequently used to update the time-series of observation stations. The collected data was combined with the data from the National Weather Service observation network for composing maps on distribution of precipitation, minimum air temperature, snow thickness and other meteorological indicators. Those maps are available in agrometeorological reviews on the Estonian Crop Research Institute website www. etki.ee. At the end of year, the weather review together with drawings and data received from observation network on hazardous phenomena will be transferred to the library of the Estonian Naturalists' Society.

The Jõgeva amateur weather observation centre has developed cooperation with the NGO Miinus 43.5, responsible for organizing traditional Icicle-Winter Festivals at Jógeva. Besides entertainment the event also provides insight into weather and climate science.

The meeting of amateur meteorologists and thunder observers was held at Jäneda on August 6. Eight scientific talks were given at the meeting, followed by an excursion.

The Estonian Teriological Society - the Teriology Autumn School on the topic "Nature and Capitalism" was held on September 23-25 at Laelatu Biological Station, Lääne County. The programme was made up of ten parts, including lectures, workshops, discussions, hikes, etc. 49 participants (schoolchildren, university students, researchers, huntsmen, environmental activists, officials and hobby naturalists).

The Section of Anthropology organised "Aul's Day" in honour of the anthropologist Juhan Aul on October 20, jointly with the Physical Anthropology Centre of the University of Tartu. Five scientific reports were presented.

The Estonian Mycological Society organised two training courses on determination of mushroom species at Pedase in Harju County: the spring camp on May 5-7 (23 participants) and the autumn camp on September 22-25.

Annual meeting of the Mycological Society "Actiones" took place on December 10 in the study halls of Natural History Museum of the University of Tartu. During this day eight scientific reports were presented. 
In cooperation with the University of Tartu, Folia Cryptogamica Estonica 53 was published

The Section of Forestry, together with Estonian University of Life Sciences, organized the seminar "Is forest management sustainable in Estonia?" which took place on January 11, 2017 (the preparations started in 2016).

Members of The Estonian Malacological Society finished the national monitoring sub-programme "Field guide of terrestrial snails".

\section{Library}

In December 2016, 161699 printed items were recorded in the ENS library. In 2016, the Library acquired 77 new books and 177 periodicals. Publications were exchanged with 30 institutions and organisations from 14 countries.

\section{Publications of the ENS in 2016:}

Laanisto, L., Öpik, M., Vanatoa, A., Tammaru, T., Gimbutas, M., Tinn, O., Kull, K. (eds). Elu varjatud mustrid [Life's hidden patterns]: Schola biotheoretica XLII. Tartu, 2016, 172 pp. (in Estonian).

Nemliher, R., Nirgi, T., Amon-Veskimeister, L. (eds). Meri [Sea]: Schola geologica XII. Tartu, 2016, 135 pp. (in Estonian).

Folia Cryptogamica Estonica 53. Tartu, 2016, 126 pp. (in cooperation with the Institute of Ecology and Earth Sciences of the University of Tartu and the Institute of Mining of the Tallinn University of Technology). 